\title{
Investigation of the History Education Researches in Turkey in Terms of Some Variables (Master's Theses and Dissertations Sample) ${ }^{\mathbf{i}}$
}

\author{
Mehmet Elban \\ Department of Social Sciences Education, Faculty of Education, Bayburt University, Turkey
}

Copyright $(2017$ by authors, all rights reserved. Authors agree that this article remains permanently open access under the terms of the Creative Commons Attribution License 4.0 International License

\begin{abstract}
The purpose of this research study is to examine the master's theses and dissertations carried out about history education research in Turkey in terms of certain variables. The study is a qualitative research and it used documentary research design as a research method. The population of the research study is the master's theses and dissertations done in the field of history education in Turkey. No sampling was used in the study but 176 master's theses and dissertations obtained from YOK National Theses Centre data base with open access were included in the study by 18 June, 2016 . Document analysis is the data collection method of the research and content and document analysis are used for data analysis. As a result of the study, it was revealed that most of the master's theses and dissertations in the field history education in Turkey were carried out in Gazi University. Moreover, the subjects of the master's theses and dissertations were mostly concentrated on teaching history and teaching of subjects, skills, and concepts. The least studied subjects were local and oral history. Nearly more than $50 \%$ of the master's theses and dissertations were carried out with quantitative method. Discussions on identity in history education before 1990 occupied a very small place in master's theses and dissertations.
\end{abstract}

Keywords Turkey, Master's Theses and Dissertations, History Education, History Teaching

\section{Introduction}

In the sense of formal education, the history of history education in Turkey dates back to the $19^{\text {th }}$ century which was the Great Depression period for Ottoman Empire and when such concepts as patriotism and citizenship triggered by the movement of ideas like Turkism and Ottomanism were tried to be adopted administratively. History and history education had become a very important reference point for the solution of the national identity crisis experienced in this period.

After the $1900 \mathrm{~s}$, the search in history education continued and with the foundation of Turkish Republic, history education took shape in line with the philosophy of the foundation of the Republic [1]. In-between these two periods, Ziya Gökalp, like E. Durkheim, evaluated history as two types: scientific and national history [2]. According to Ziya Gökalp, one of the leading intellectuals in the philosophy of the foundation of the Turkish Republic, one of them is real history which discusses events in a cause and effect relationship using historical sources like documents and monuments and the other one is national history whose major aim is pedagogy and which aims at teaching children their ancestors' heroic deeds which they would be proud of and having them love their motherland and people. [3]. In the early years of the Republic, there were some studies of educators on history education like İsmail Hakkı Baltacıoğlu and İhsan Sungu [2,4]. The studies carried out in the field of pedagogy in history education were quite rare in these years. After the death of Mustafa Kemal Atatürk, the studies intended for history education were again approached in terms of national identity and political centre. This condition continued till 1990s. Before the 1990s, another study about pedagogy in history education was carried out by A.Fuat Baymur in 1941. In Baymur's work, such subjects as using materials about history education and teaching methods were explained. [5].

In addition, UNESCO and the European Council carried out a study to revise history and geography books after the pitiful experiences of the Second World War and the Turkish representatives also took part in this work. Moreover, the books called "History Teaching and History Textbook Revision" written by Otto-Ernst SCHUEDDEKOF, Edouard BRULEY, E.H. DANCE and Haakon VIGANDER and the book called "The Place of History in Secondary Teaching" written by E.H. DANCE, the products of the studies carried out by the European Council, were translated into Turkish in 1969[6] and 1971[7] by Ministry of National Education. The 
prominent historians and intellectuals in Turkey discussed historiography and history education within the framework of a seminar by the Philosophy Association in 1974. While history education in high schools and in higher education was discussed in the seminar, identity and politics became the centre stage for the discussions. Pedagogy was placed less emphasis in history education [8]. In the 1990s, the Board of Education and Discipline oriented towards social and cultural history in textbook contents rather than political history to prevent hostility towards "others" in 1992 and took a step towards a "peaceful" language [9]. A comprehensive symposium on textbooks was held in İzmir in 1994. The condition of the history textbooks in the past and their future were discussed in the symposium [10]. A congress about "Problem of The Other in History" was held in Boğazici University in 1995. Evaluations and warnings were made about the narratives set on the "other" in history education in the symposium [11]. A symposium about history and geography education in the USA, Germany, France, and Turkey was organized in Ankara University in 1997. The corresponding countries' textbooks were discussed in the symposium [12]. A panel called "What Can History Textbooks Cover?" was organized by the Turkish Historical Association, Ministry of National Education, and Turkish National Commission for UNESCO in 1998. The opinions were delivered about the contents of the history textbooks in the panel discussion [13]. A workshop was carried out in Ankara in 2000 in collaboration with Friedrich Ebert Foundation and history education was discussed with its different aspects in the workshop [14]. Another development which led to the radical changes in history education in Turkey was due to the Recommendations of 31 October 2001 adopted by the Committee of Ministers of the European Union [9].

European and Turkish history educators got together in collaboration with European Union, Friedrich Ebert Foundation, and Goethe Institute in 2002. Papers were presented in this meeting about such topics as student-centred approaches in history education, social history, and European awareness [15]. Studies carried out institutionally about history teaching and education has increased so significantly since 2002 that it cannot be explained in this study. Another important development was that the number of educational institutions in universities in Turkey increased after the 2000s. Thus, the number of master's theses and dissertations on history education and teaching increased. This study discusses the studies carried out in the master's theses and dissertations in the field of history education in Turkey. Within this context, this study sought to answer the following questions:

1. What is the distribution of master's theses and dissertations carried out in the field of history education in terms of universities and years?

2. What is the distribution of master's theses and dissertations carried out in the field of history education in the study in terms of research topics?
3. What is the distribution of the research designs used in the master's theses and dissertations carried out in the field of history education in the study?

4. What is the distribution of the quantitative data analysis approaches used in the master's theses and dissertations carried out in the field of history education in the study?

5. What is the distribution of the qualitative data analysis approaches used in the master's theses and dissertations carried out in the field of history education in the study?

6. What is the distribution of the unspecified method points used in the master's theses and dissertations carried out in the field of history education in the study?

\section{Method}

The research study is a qualitative study and a documentary research is used as a research model. When there are no direct observations and interviews in qualitative research studies, the outside sources like written and visual materials related to the research problem can be used. Thus, document analysis or examination can be used as a research model alone [16].

\subsection{Population and Sample}

The population of the study is the master's theses and dissertations carried out in the field of history education in Turkey. Sampling is not used in the study so all of the open access master's theses and dissertations were included within the context of the research study. Thus, 176 open access master's theses and dissertations obtained from YOK National Theses Centre data base were included in the study by 18 June, 2016.

\subsection{Data Collection and Analysis}

The research data were obtained via document analysis $[16,17]$. Document analysis and content analysis were used for the analysis of research data. As a result of the analysis, the findings obtained were evaluated by descriptive statistics like frequencies and percentages. The reliability of coding technique was administered for the reliability of content analysis. The reliability coefficient between the raters was calculated with the following formula: "Reliability=coefficient of agreement/(coefficient of agreement + coefficient of disagreement)[18]. After performing the reliability of coding, the agreement between the raters was found as $88 \%$.

\section{Findings}

The table given below presented the distribution of the 
master's theses and dissertations with regard to universities.

Table 1. Distribution of the Master's theses and Dissertations with regard to Universities

\begin{tabular}{|c|c|c|}
\hline Universities & f & Percentages (\%) \\
\hline Gazi University & 86 & 49 \\
\hline Marmara University & 21 & 12 \\
\hline Karadeniz Technical University & 21 & 12 \\
\hline Selçuk University & 9 & 5 \\
\hline Atatürk University & 9 & 5 \\
\hline Dokuz Eylül University & 7 & 4 \\
\hline Yüzüncü Yıl University & 6 & 4 \\
\hline Çanakkale Onsekiz Mart University & 5 & 3 \\
\hline Cumhuriyet University & 2 & 1 \\
\hline Beykent University & 2 & 1 \\
\hline Gaziosmanpaşa University & 2 & 1 \\
\hline Others (6 different universities) & 6 & 4 \\
\hline Total & 176 & 100 \\
\hline
\end{tabular}

As seen in Table 1, there are total 176 master's theses and dissertations in YOK National Theses Centre. Among these theses and dissertations, Gazi University has the highest share.

The table below presents the distribution of the master's theses and dissertations in terms of years.

Table 2. Distribution of the Master's Theses and Dissertations in terms of Years

\begin{tabular}{|c|c|c|c|}
\hline Year & Master's Theses & $\begin{array}{c}\text { Doctoral }(\mathrm{PhD}) \\
\text { Dissertation }\end{array}$ & Total \\
\hline 1991 & 2 & 0 & 2 \\
\hline 2000 & 1 & 0 & 1 \\
\hline 2001 & 0 & 0 & 0 \\
\hline 2002 & 3 & 0 & 3 \\
\hline 2003 & 0 & 1 & 1 \\
\hline 2004 & 8 & 0 & 8 \\
\hline 2005 & 5 & 1 & 6 \\
\hline 2006 & 14 & 3 & 17 \\
\hline 2007 & 11 & 1 & 12 \\
\hline 2008 & 17 & 1 & 18 \\
\hline 2009 & 17 & 3 & 20 \\
\hline 2010 & 12 & 4 & 16 \\
\hline 2011 & 21 & 2 & 23 \\
\hline 2012 & 13 & 6 & 19 \\
\hline 2013 & 5 & 6 & 11 \\
\hline 2014 & 9 & 2 & 11 \\
\hline 2015 & 7 & 0 & 7 \\
\hline 2016 & 1 & 0 & 1 \\
\hline Final Total & 146 & & 176 \\
\hline & & 30 & \\
\hline
\end{tabular}

As seen in Table 2, there are total 176 master's theses and dissertations in YOK National Theses Centre. Out of these 176 theses and dissertations, 146 of them are master's theses and 30 of them are $\mathrm{PhD}$ dissertations. The number of master's theses increased in 2011 and the number of doctoral dissertations increased in 2011 and 2013. Table 3 presents the distribution of the master's theses and dissertations carried out in the field of history education in universities in Turkey in terms of their subjects.

Table 3. Distribution of Master's Theses and Dissertations in terms of Their Subjects

\begin{tabular}{|c|c|c|}
\hline Subjects & $\mathrm{f}$ & Percentages (\%) \\
\hline History teaching & 68 & 38 \\
\hline Teaching subjects, skills, and concepts & 33 & 19 \\
\hline Research on history textbooks & 26 & 15 \\
\hline History of history education & 21 & 12 \\
\hline $\begin{array}{c}\text { Concepts, images, and values in history } \\
\text { education }\end{array}$ & 14 & 8 \\
\hline Local and oral history & 9 & 5 \\
\hline Curriculum & 5 & 3 \\
\hline Total & 176 & 100 \\
\hline
\end{tabular}

The most popular subject choice in the master's theses and dissertations carried out in the field of history education was history teaching $(\mathrm{f}=38)$ and the least popular subjects were curriculum ( $(\mathrm{f}=5)$ and local and oral history $(\mathrm{f}=9)$ as seen in Table 3.

Table 4 presents the distribution of the master's theses and dissertations carried out in the field of history education in universities in Turkey with regard to research methods.

Table 4. Research Methods used in Master's theses and Dissertations

\begin{tabular}{|c|c|c|}
\hline Research Method & $\mathrm{f}$ & Percentages (\%) \\
\hline Survey method & 65 & 37 \\
\hline Not specified & 34 & 19 \\
\hline Quasi-experimental method & 27 & 15 \\
\hline Mixed method & 18 & 10 \\
\hline Documentary research method & 12 & 7 \\
\hline Case study & 10 & 6 \\
\hline Historical research method & 6 & 3 \\
\hline Action research method & 3 & 2 \\
\hline Phenomenology method & 1 & 1 \\
\hline Total & 176 & 100 \\
\hline
\end{tabular}

As shown in Table 4, the master's theses and dissertations carried out in the field of history education in universities in Turkey used survey method mostly $(\mathrm{f}=65)$ and the least popular research method used was phenomenology $(\mathrm{f}=1)$. The table presenting the quantitative data analysis methods used in the master's theses and dissertations carried out in the field of history education in universities in Turkey was given below. 
Table 5. Quantitative Data Analysis Methods Used in Master's Theses and Dissertations

\begin{tabular}{|c|c|c|}
\hline Quantitative Data Analysis Methods & f & Percentages (\%) \\
\hline Inferential Statistics & 62 & 60 \\
\hline Descriptive Statistics & 41 & 40 \\
\hline Total & 103 & 100 \\
\hline
\end{tabular}

As seen in Table 5, the most popular method used in the master's theses and dissertations carried out in the field of history education in universities in Turkey was inferential statistics $(f=62)$ but phenomenology was the least popular research method $(\mathrm{f}=1)$.

The table below presents the qualitative data analysis methods used in the master's theses and dissertations carried out in the field of history education in universities in Turkey.

Table 6. Qualitative Data Analysis Methods Used in Master's theses and Dissertations

\begin{tabular}{|c|c|c|}
\hline Qualitative Data Analysis Methods & $\mathrm{f}$ & Percentages $(\%)$ \\
\hline Content analysis & 19 & 41 \\
\hline Descriptive analysis & 8 & 18 \\
\hline Document analysis & 6 & 13 \\
\hline Descriptive analysis + content analysis & 6 & 13 \\
\hline $\begin{array}{c}\text { Others (Comparative, Inductive, and } \\
\text { deductive) }\end{array}$ & 4 & 9 \\
\hline $\begin{array}{c}\text { Descriptive }+ \text { content analysis }+ \text { discourse } \\
\text { analysis }\end{array}$ & 2 & 4 \\
\hline Document analysis + descriptive analysis & 1 & 2 \\
\hline Total & 46 & 100 \\
\hline
\end{tabular}

As shown in Table 6, the master's theses and dissertations carried out in the field of history education in universities in Turkey mostly used content analysis $(\mathrm{f}=19)$.

The points not specified in methods in the master's theses and dissertations carried out in the field of history education in universities in Turkey were presented below.

Table 7. Unspecified points in Methods Section in Master's theses and Dissertations

\begin{tabular}{|c|c|c|}
\hline Points not specified in Methods Section & $\mathrm{f}$ & Percentage (\%) \\
\hline Data analysis and data analysis procedure & 98 & 29 \\
\hline Reliability of data collection tool & 69 & 21 \\
\hline Sampling method & 61 & 18 \\
\hline Data collection tool & 41 & 12 \\
\hline Research method & 34 & 10 \\
\hline Population of the study-sampling & 33 & 10 \\
\hline Total & 46 & 100 \\
\hline
\end{tabular}

As seen in Table 7, data analysis and data analysis processes were not mentioned in the master's theses and dissertations carried out in the field of history education in universities in Turkey $(\mathrm{f}=98)$.

\section{Conclusion and Recommendations}

The master's theses and dissertations in the field of history education were mostly carried out in Gazi University, Marmara University, Karadeniz Technical University, Selçuk University, Atatürk University and Dokuz Eylül University. The number of the master's theses and dissertations increased mostly in 2011. The total number of master's theses and doctoral dissertations is 176 . This number is not a sufficient number. Similarly, the number of master's theses and doctoral dissertations in the field of computer and instructional technology is also not sufficient. The lack of theses and dissertations in the field of education is due to the lack of academicians who will direct master or doctoral programs and their thesis and dissertations [19]. Moreover, the increase in the number of educational institutes has been after years of 2000 .

The subjects of the master's theses and dissertations carried out in the field of history education mostly concentrated on teaching of history and teaching subjects, skills, and concepts. The scope of these theses is the use of museum in history teaching, measurement and evaluation, the use of graphic, the use of computer, the use of map, the use of discussion method, the use of novel, the use of reminiscent strategies, the use of small group discussions, the use of concept maps, the use of newspapers, the use of biographies, the use of documentary and film. Other topics in this scope are the use of document, instructional strategy, project work, success, interest, readiness, attitudes, academic achievement, teacher teaching approach, learning styles of learners, constructivist education, multiple intelligence, teaching technique, teaching model and student centered methods. The subjects in the dimension of topic, skill, and concept teaching are the skills, historical language, causality, historical empathy, historical time, national struggle topics, art history, republican history, Ottoman modernization, Kemalism, Tanzimat period, geographical concepts, ancient history, concept misconceptions, war and peace topics, Turkish history and world history. Another subject that has been studied in postgraduate theses in history education is the history textbooks research. The contents of history textbook research include national identity in history textbooks, materials used in history textbooks, images in history textbooks, student and teacher views for history textbooks, national festivals in history textbooks, and Turks in history textbooks and the Ottoman image in the history textbooks. The master's theses and doctoral dissertations topics constitute the historical content of history education are history in republic period, history education in Ottoman period, history education in the period of different political rulings, history education in the USA, history education in Europe, history education in private training center, history education in Turkic republics, historical education in Mongolia and history education in private schools. The postgraduate thesis and dissertations topics that constitute the content of concepts, images and values in history education are patriotism, multiculturalism, tolerance education, European Union image, nationalism, citizenship, democracy, national festivals, and female image. The least 
popular subjects studied were local and oral history. Considering this result, problem-oriented and solution-oriented research studies can be carried out in the master's theses and dissertations in the field of history education. On the other hand, thesis advisors may direct their students to existing problems in history education and teaching, while determining thesis subjects [20]. Thus, the master's theses and dissertations conducted were mostly descriptive studies. Nearly more than $50 \%$ of the master's theses and dissertations in history education were carried out via quantitative research method. Survey and semi-experimental investigations are the most commonly used quantitative methods. The reason why the survey method is very popular can be explained by the fact that the method reflects the attitudes, values and beliefs of the learners, teachers and other parties in a good way. The choice of semi-experimental studies can be attributed to the fact that these studies are studies investigating the cause-and-effect relationship [19]. Experimental research and survey research are the most preferred method of research in doctoral dissertations in educational sciences. It has been proposed to reduce the use of survey and experimental models for this situation [21]. Considering that these research studies used questionnaires as a data collection tool and general opinions were expressed in surveys, it was found that the qualitative method which has a deeper insight into the phenomenon under the study was needed in history education research studies. Similarly, in master's theses and doctoral dissertations conducted in Turkish teaching, the questionnaire is a widely used data collection tool [20]. However, the qualitative research which is an in-depth study of the subjects like action research and phenomenology constituted only $3 \%$ of the master's theses and dissertations carried out in the field of history education. On the other hand, mixed research methods which make up the shortcomings of both qualitative and quantitative research methods composed only $10 \%$ of the master's theses and dissertations carried out in the field of history education. Finally, the master's theses and dissertations carried out in the field of history education in Turkey via qualitative research methods and mixed research methods can be increased more in number. Thus, more in-depth information can be revealed. The same suggestions have been made in researches on master's theses and doctoral dissertations made in the field of Turkish teaching [20]. On the other hand, in the postgraduate theses made with quantitative research methods, new scales can be developed and the scales widely used in history education and teaching can be adapted to Turkish.

$60 \%$ inferential statistics and $40 \%$ descriptive statistics were used in the quantitative data analysis for the master's theses and dissertations carried out in the field of history education. Content analysis and document analysis were used mostly for qualitative data analysis.

$19 \%$ of the master's theses and dissertations carried out in the field of history education did not mention research methods. The other points which did not give information about the research method were mostly data analysis and data analysis processes, the reliability of data collection tool, sampling method, data collection tool and the population-sample, respectively.

Such a result occurs due to the lack of applicability of educational research methodology in the newly founded educational institutions. In this case, the students involved in the postgraduate programs should be mainly given educational research methodology course. Likewise, the same recommendations were made by Demircioğlu [22]. Similar problems were found in doctoral dissertations in the field of educational sciences. It has been proposed to increase the number of hours of research methods and statistical lessons for mentioned problems [21].

Another result revealed in the research is that the master's theses and dissertations carried out in the educational institutions which opened after the 1990s addressed the national identity discussions less than before the 1990s when they were the primary focus of history education. Pedagogy-oriented subjects like teaching strategies and techniques and concept teaching were mostly studied in these theses. In other words, identity discussions in history teaching before 1990 devoted too little space in the master's theses and dissertations. This result reveals that the little attention given to the pedagogy before the 1990s increased considerably in the master's theses and dissertations carried out in the field of history teaching after the 1990s. In the following period, it is thought to be beneficial to make postgraduate theses on topics such as teaching of special topics, teaching controversial topics, historiography, gender. History education approaches such as China, Korea, and Japan can be studied in the historical dimension of history education. Likewise, postgraduate theses on history education studies in southern and northern African countries can be conducted.

\section{REFERENCES}

[1] Çapa, M. (2002). Cumhuriyet'in ilk yıllarında tarih öğretimi. Ankara Üniversitesi Türk İnkılâp Tarihi Enstitüsü Atatürk Yolu Dergisi, 29(30), 39-55.

[2] Safran, M. (2002). Türk tarih öğretimi ve meseleleri. Hasa Celal Güzel, Kemal Çiçek, Salim Koca (Ed.), Türkler ansiklopedisi 17 içinde (s.935-942). Ankara: Yeni Türkiye yayınları.

[3] Gökalp, Z. (2011). Tarih ilim mi? yoksa sanat mı?. Ahmet Simşek ve Ali Satan (Ed.) Milli Tarih İnşası içinde (s.47-48). İstanbul: Tarihçi yayınları. (Gökalp, 2011, s.47-48).

[4] Ata, B. (2003). Mülkiyeli bir eğitim bilimci: Ihsan Sungu. Türk Eğitim Bilimleri Dergisi, 1 (2), 233-243.

[5] Baymur, A.F. (1941). Tarih öğretimi. Ankara: Gazi Terbiye Enstitüsü Yayınları. 
[6] Otto, E.S., Edouard, B., Dance, E.H. ve Vigander, H. (1969), Tarih Öğretimi ve Tarih Kitaplarının Geliștirilmesi, (Çev.Necati Engez), İstanbul: Milli Eğitim Basımevi

[7] Dance, E.H. (1971), Orta Dereceli Okullarda Tarihin Yeri, (Çev.Osman Horasanl1), İstanbul: Milli Eğitim Basımevi

[8] Felsefe Kurumu, (1977). Felsefe kurumu seminerleri. Ankara: Türk Tarih Kurumu Yayınları.

[9] Safran, M. (2008). Türkiye'de tarih eğitimi ve öğretimi. Mustafa Safran ve Dursun Dilek (Ed.) 21. yüzyılda kimlik, vatandaşlık ve tarih eğitimi içinde (s.13-21). İstanbul: Yeni İnsan yayınları.

[10] Özbaran, S. (Ed.), (1998). Tarih öğretimi ve ders kitapları.İzmir: Dokuz Eylül Yayınları.

[11] Berktay, A.ve Tuncer, H.C. (1998). Tarih Eğitimi ve Tarihte "Öteki Sorunu, İstanbul: Tarih Vakfi Yurt Yayınları.

[12] Ankara Üniversitesi, (1998). Amerika Birleşik Devletleri, Almanya, Fransa ve Türkiye'de tarih ve coğrafya eğitimi. Ankara: Ankara Üniversitesi yayınları.

[13] Özbaran, S. (2003). Güdümlü Tarih. (1.Basım), İstanbul: Cem Yayınevi.

[14] TETTV, (2000). Tarih öğretiminin yeniden yapilandirilmasi. İstanbul: TETTV yayınları.
[15] TETTV, (2003). Tarih eğitimine eleştirel yaklaşimlar. İstanbul: TETTV yayınları.

[16] Yıldırım, A. ve Şimşek, A. (2013). Sosyal bilimlerde nitel araştırma yöntemleri. (9.Baskı), Ankara: Seçkin yayınları.

[17] Merriam, S.B. (2013). Nitel araştırma-desen ve uygulama için bir rehber-Oualitative research a guide to desing and inplementation. (Selahattin Turan, Çev. Ed.), Ankara: Nobel yayınları.

[18] Miles, M. B. ve Huberman, A. M. (2015). Nitel veri analizi (1. Baskı). (Çev. S. Akbaba Altun, \& A. Ersoy, Ankara: Pegem akademi yayınları.

[19] Erdoğmuş, F. U.ve Çağıltay, K. (2009). Türkiye'de eğitim teknolojileri alanında yapılan master ve doktora tezlerinde genel eğilimler. Akademik Bilişim. Akademik Bilişim Konferansı Bildirileri Harran Üniversitesi.

[20] Yağmur Şahin, E., Kana, F., \& Varışoğlu, B. (2013). Türkçe eğitimi bölümlerinde yapılan lisansüstü tezlerin araştırma eğilimleri. International Journal of Human Sciences, 10(2), 356-378.

[21] Karadă̆, E. (2010). Eğitim bilimleri doktora tezlerinde kullanılan araştırma modelleri: Nitelik düzeyleri ve analitik hata tipleri. Kuram ve Uygulamada Eğitim Yönetimi, 1(1), 49-71.

[22] Demircioğlu, İ.H. (2014). Türkiye' de tarih eğitimi: Sorunları ve çözüm önerileri. Yeni Türkiye, 10(59), s.1176-1186.

${ }^{\mathrm{i}}$ This article was presented at IV International Symposium on History Education as an oral presentation 